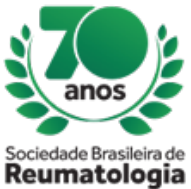

CENTRO DE EVENTOS DO CEARÁ O4 A 07 DE SETEMBRO

\title{
TRACTION DYNAMOMETRY AND PHYSICAL PERFORMANCE FOR THE EVALUATION OF SARCOPENIA IN COMMUNITY INDEPENDENT ELDERLY
}

Viviane Cristina Uliana Peterle (Faculdade de Medicina - Escola Superior de Ciências da Saúde, Brasília, DF, Brasil), Ana Paula Monteiro Gomides Reis (Faculdade de Medicina - Centro Universitário de Brasília, Brasília, DF, Brasil), João Carlos Geber Júnior (Departamento de Clínica Médica - Hospital Alvorada Brasília, Brasília, DF, Brasil), Victor Hudson de Lacerda Borges (Faculdade de Medicina - Escola Superior de Ciências de Saúde, Brasília, DF, Brasil), Camila Padatella Jaime (Residência Médica do Hospital do Paranoá - Secretaria de Saúde do Distrito Federal, Paranoá, DF, Brasil), Denise Peres de Mendonça (Residência Médica do Hospital do Paranoá - Secretaria de Saúde do Distrito Federal, Paranoá, DF, Brasil), Fernanda Medeiros Araújo (Residência Médica do Hospital do Paranoá - Secretaria de Saúde do Distrito Federal, Paranoá, DF, Brasil), Ludmila Naves Marinho (Residência Médica do Hospital do Paranoá - Secretaria de Saúde do Distrito Federal, Paranoá, DF, Brasil), Igor Borges Paulino Silva (Residência Médica do Hospital do Paranoá - Secretaria de Saúde do Distrito Federal, Paranoá, DF, Brasil), Raimundo Nonato Barboza Guerra Júnior (Residência Médica do Hospital do Paranoá - Secretaria de Saúde do Distrito Federal, Paranoá, DF, Brasil), Vitor Abranches Jordão Costa (Residência Médica do Hospital do Paranoá - Secretaria de Saúde do Distrito Federal, Paranoá, DF, Brasil), Vitor César de Sousa Neri (Residência Médica do Hospital do Paranoá - Secretaria de Saúde do Distrito Federal, Paranoá, DF, Brasil), Larissa Santos da Luz (Residência Médica do Hospital do Paranoá - Secretaria de Saúde do Distrito Federal, Paranoá, DF, Brasil), Hugo Miranda da Silva Barroso (Residência Médica do Hospital do Paranoá - Secretaria de Saúde do Distrito Federal, Paranoá, DF, Brasil), Maria Clara Vaz Cabral Marques (Residência Médica do Hospital do Paranoá - Secretaria de Saúde do Distrito Federal, Paranoá, DF, Brasil), Tereza Bastos (Residência Médica do Hospital do Paranoá - Secretaria de Saúde do Distrito Federal, Paranoá, DF, Brasil), Vaneide Luna (Residência Médica do Hospital do Paranoá - Secretaria de Saúde do Distrito Federal, Paranoá, DF, Brasil), Alan Guimarães Fontenele (Residência Médica do Hospital do Paranoá - Secretaria de Saúde do Distrito Federal, Paranoá, DF, Brasil)

\section{BACKGROUND}

Sarcopenia is a syndrome characterized by progressive decrease of mass, strength and muscle function, being poor physical performance as indicative of severe sarcopenia. The association of mass reduction and lack of muscle strength results in a greater risk of falls, hospitalizations, dependence, institutionalization, worsening of quality of life and mortality.

\section{MATERIALS AND METHODS}

A cross-sectional study was carried out with 49 elderly women (> 60 years old) who were independent in an Elderly Center in which the following tests were performed: 1) Anthropometric Assessment 1.1) BMI was obtained by the result of the ratio between body weight in kilograms and height in meters squared $\left(\mathrm{IMC}=\right.$ weight $/$ height $\left.^{2}\right)$; 1.2) Calf Circumference being considered sarcopenia values $<31 \mathrm{~cm}$. 2) Functional performance evaluation: 2.1) The manual traction force (MTF) was evaluated in kilograms (kg) using the Elastic @ digital dynamometer; 2.2) Test of Speed of March (MV) where the time used to complete the course was divided by the distance of $10 \mathrm{~m}$, providing the measurement of the speed of march $(\mathrm{m} / \mathrm{s})$; 2.3) Timed Up and Go (TUG) test in which the elderly woman should get up from a chair without the help of her arms and walk at a comfortable pace from a distance of three meters, turn around, return and sit again.

\section{RESULTS}

39 elderly women with an average age of 70.3 years $(60$ - 93) with an average BMI of $27.94 \mathrm{~kg} / \mathrm{m} 2(22.03$ - 34.95) and an average circumference of the calf were $35.39 \mathrm{~cm}(45.17-31.5)$ [VR $\leq 31 \mathrm{~cm}]$. Regarding 
evaluation of upper limb strength, the average of the manual traction force performed by the right elbow flexion was $7.94 \mathrm{Kgf}(3.2-12.8)$ and the squatting force testing the lower limbs was $21.32 \mathrm{Kgf}(7-42.4)$. The average velocity tests of $0.62 \mathrm{~m} / \mathrm{s}(0.37-0.96)$ [VR $\leq 0.8 \mathrm{~m} / \mathrm{s}$ ] and the TUG of 10.34 (6.7 - 18.5) [VR: up to $12.4 \mathrm{~s}$ ] completed the physical performance assessment.

\section{CONCLUSION}

The sample analysis reveals a population with more advanced and overweight age group. In parallel, despite the averages of strength and physical performance that assess the risk for falls being within normal range, a large standard deviation is revealed showing the particularities of aging. Understanding the factors involved in this process in Brazil is necessary to promote policies and management appropriate to the profile of our population, which will significantly reduce morbidity and socioeconomic costs. 